\title{
Distribution of Particulate Matter in Cawthorne Channels Air Basin in Nigeria
}

\author{
Ini U. Ubong ${ }^{1}$, Uwem U. Ubong ${ }^{2}$, Etim U. Ubong ${ }^{3}$, Roy Ukonta ${ }^{4} \&$ David Ishmael $^{5}$ \\ ${ }^{1}$ Institute of Pollution Studies, Rivers State University of Science and Technology, Port Harcourt, Rivers State, \\ Nigeria \\ ${ }^{2}$ Dept of Chemistry, Akwa Ibom State University, Mkpat Enin Main Campus, Akwa Ibom State, Nigeria \\ ${ }^{3}$ Center for Fuel Cell Systems Research \& Powertrain Integrations, Kettering University, Flint, USA \\ ${ }^{4}$ Shell Dev. Co. of Nig., SPDC, ENV. Port Harcourt, Nigeria \\ ${ }^{5}$ Faithlink Consult Nigeria Limited, Stadium Road, Elekahia, Port Harcourt, Nigeria \\ Correspondence: Ini Udosen Ubong, Institute of Pollution Studies, Rivers State University of Science and \\ Technology, Port Harcourt, Rivers State, Nigeria. E-mail: iniubong12@hotmail.com
}

Received: March 22, 2015 Accepted: April 1, 2015 Online Published: June 28, 2015

doi:10.5539/ep.v4n3p19 URL: http://dx.doi.org/10.5539/ep.v4n3p19

\begin{abstract}
The concentrations of Particulate Matter (PM) were determined in tropical wetlands air basin of Cawthorne Channel, Awoba and Krakrama. The sampling was performed with well calibrated equipment (A MultiRAE PLUS (PGM - 50), a programmable Multi Gas monitor with an electrochemical sensor). Parameters measured were particulate matter with $1 \mu \mathrm{m}, 2.5 \mu \mathrm{m}\left(\mathrm{PM}_{2.5}\right), 7 \mu \mathrm{m}\left(\mathrm{PM}_{7}\right), 10 \mu \mathrm{m}\left(\mathrm{PM}_{10}\right)$ and Total suspended particulate (TSP). Seasonal variations were displayed by all fractions of particulate matter. TSP at Cawthorne Channels was observed, with very high concentration in January $\left(346.1 \mu \mathrm{g} / \mathrm{m}^{3}\right)$ at the upwind and $\left(401.7 \mu \mathrm{g} / \mathrm{m}^{3}\right)$ downwind in dry season. This was followed by wet season measurement. The $\mathrm{PM}_{10}$ results at Cawthorne Channels also showed strong seasonal variations with very high concentration in January $\left(313.6 \mu \mathrm{g} / \mathrm{m}^{3}\right)$ at the upwind and $\left(367.5 \mu \mathrm{g} / \mathrm{m}^{3}\right)$ downwind. Of all the respirable particulate size fractions studied, allowable International Standard according to USEPA (1990), was exceeded in $\mathrm{PM}_{10}$ and $\mathrm{PM}_{7} . \mathrm{PM}_{2.5}$ had values that were generally below 60.0 $\mu \mathrm{g} / \mathrm{m}^{3}$ while $\mathrm{PM}_{1}$ had values below $10.0 \mu \mathrm{g} / \mathrm{m}^{3}$. The TSP levels exceeded $250.0 \mathrm{ug} / \mathrm{m}^{3}$, being Nigerian National allowable limit. The respirable particulate matter had no statistical difference between the upwind and downwind directions $(\mathrm{p}<1)_{0.05}$.
\end{abstract}

Keywords: suspended particulate matter (SPM), particulate fraction distribution, tropical wetlands and air basin

\section{Introduction}

Increase in particulate matter air contamination and their negative impacts on human health have resulted in efforts to monitor and identify the various fractions. The particulate mass concentrations in a very clean urban environment are about $10 \mu \mathrm{g} . \mathrm{m}^{-3}$ (Estokova \& Stevulova, 2012).

The production of atmospheric aerosols or atmospheric particulate matter by anthropogenic processes is of great concern. The effects of inhaling particulate matter have been widely studied in humans and animals and include asthma, lung cancer, cardiovascular issues, and premature death (Pope \& Burnett, 2002). The size of the particle is a main determinant of where in the respiratory tract the particle will reside when inhaled. Larger particles are generally filtered in the nose and throat and do not necessarily cause problems, but particulate matter smaller than 10 micrometers $(\mu \mathrm{m})$, referred to as $P M_{10}$, can settle in the bronchi and lungs and cause health problems (Kaonga \& Kgabi, 2009).

Air pollutants are sometimes classified into Suspended Particulate Matter, SPM (dusts, fumes, mists, and smokes) and gaseous pollutants (gases and vapors).

Particulate matter is the sum of all solids and liquid particles suspended in air, many of which are hazardous (Greenfacts, 2015; Estokova \& Stevulova, 2012). This complex mixture includes both organic and inorganic particles, such as dust, pollen, soot, smoke, and liquid droplets. The atmosphere contains particle sizes ranging from slightly larger than molecules up to hundreds of micrometers, which consists of a variety of chemical 
compounds (Hinds, 1999; Estokova \& Stevulova, 2012). Depending on their lifetime, the particulates observed at a location can be both of local origin or the product of the transport over distances of hundreds to thousands kilometers. These particles vary greatly in size, composition, and origin.

Based on size, particulate matter is often divided into two main groups (Morawska \& Salthammer, 2003; USEPA, 2012; Estokova \& Stevulova, 2012): The coarse fraction which contains the larger particles with a size ranging from 2.5 to $10 \mu \mathrm{m}\left(\mathrm{PM}_{2.5}-\mathrm{PM}_{10}\right)$. The fine fraction contains the smaller ones with a size up to $2.5 \mu \mathrm{m}\left(\mathrm{PM}_{2.5}\right)$. The particles in the fine fraction which are smaller than $0.1 \mu \mathrm{m}$ are called ultrafine particles (Estokova \& Stevulova, 2012; US EPA, 2012, Greenfacts, 2015).

Coarse Particles (CP) include all particles with an aerodynamic diameter (diameter of a sphere with unit density and mass equal to the mass of the provided particle) greater than 2.5 micrometers and less than 10 micrometers.

These particles are identified as $\mathrm{PM}_{2.5-10}$. $\mathrm{PM}_{10}$ is an abbreviation used for so called "thoracic" particles with the diameter under $10 \mu \mathrm{m}$. Fine Particles (FP) include all particles having an aerodynamic diameter less than 2.5 micrometers and greater than 0.1 micrometers (PM 2.5). Ultrafine Particles (UFP) include all particles with the aerodynamic diameter of less than 0.1 micrometers (Estokova \& Stevulova, 2012).

Seinfeld and Pandis (2006), reported that the 10 micrometer $(\mu \mathrm{m})$ particle size does not represent a strict boundary between respirable and non-respirable particles, but has been agreed upon for monitoring of airborne particulate matter by most regulatory agencies. Similarly, particles smaller than 2.5 micrometers, PM 2.5, tend to penetrate into the gas-exchange regions of the lungs, and very small particles $(<100$ nanometers $)$ may pass through the lungs to affect other organs (Kaonga \& Kgabi, 2009). In particular, a study by Pope and Burnett (2002), indicated that $\mathrm{PM}_{2.5}$ leads to high plaque deposits in arteries, causing vascular inflammation and atherosclerosis - a hardening of the arteries that reduces elasticity, which can lead to heart attacks and other cardiovascular problems.

JOKSIĆ, et al. 2009, studied daily deposits of $\mathrm{PM}_{10}, \mathrm{PM}_{2.5}$ and $\mathrm{PM}_{1}$ aerosol fractions which were collected during spring and autumn sampling periods in 2007 in Belgrade.

Comprehensive toxicological and epidemiological studies conducted over the last decades have indicated that human exposure to such small airborne particles (PM 10 and less) have adverse health effects and may be a cause of a number of respiratory and cardiovascular inflammations (Gwinn \& Vallyathan, 2006). During inhalation, the coarse particulate fraction usually remains in the upper part of the airways and lungs but the fine particles penetrate deeper and reach the alveolar region (Josic et al., 2009). The chemical composition of air particulate matter fractions thus becomes very important and engrosses both scientific and public auditory (Heal et al., 2005; Reiss et al., 2007).

In a number of studies, investigators have observed an increased incidence of respiratory diseases in association with $\mathrm{PM}_{10}$ air pollution. For example, in a study conducted in the United Kingdom, an association between emergency hospital admissions for respiratory and cardiovascular disease and $\mathrm{PM}_{10}$ was found (Atkinson, 1999). In another study conducted in Seattle, Washington, the result demonstrated association with emergency room visits for asthmatics and $\mathrm{PM}_{10}$ air pollution (Schwartz, 1993). Also, $\mathrm{PM}_{10}$ was associated with an increase in hospital admission of the elderly for Chronic Obstructive pulmonary disease (COPD) and asthma and lower respiratory tract infections including bronchitis and pneumonia (Schwartz, 1993; Burnett, 1997; Atkinson, 1999).

Epidemiological studies have shown the relationship between $\mathrm{PM}_{10}$ exposure and an increase in bronchitis, chronic cough, and respiratory symptoms in persons with chronic obstructive pulmonary disease (COPD) (Abbey, et al., 1995; Pope, et al., 1995).

So far, studies to date have shown a dearth of information on particulate matter in the Niger delta. There is need to generate reference data to document the different size fractions of particulate matter at Cawthorne Channels, Awoba and Krakrama rural wetlands air basins. This study is different in the sense that it will characterize and document the existing levels of particulate fraction in this geographical region. This has not been done before for this area and will bridge the gap in information needs while providing a bench mark for future studies in the Niger Delta air basin. The primary objective of this study was to characterize and document particulate matter fractions in the Cawthorne Channel air basin with a view to providing baseline data for the geographical region. Cawthorne channel 2, where sampling was done, is located within Latitude $4^{\circ} .55513 \mathrm{~N} \mathrm{~N}$ and Longitude $6^{0} .00282 \mathrm{E}$; and is located some $25 \mathrm{~km}$ south of Port Harcourt in Rivers State of Nigeria. Similarly, Awoba sampling site has the following co-ordinates: $4^{\circ} .53165^{\prime \prime} \mathrm{N}$ and $6^{\circ} .81959 " \mathrm{E}$. This is located at the southern bank which branches off Sombreiro River (Figure 1). Krakrama location sampling point is within the co-ordinates: $4^{\circ} .55174 " \mathrm{~N}$ and $6^{\circ} .90045^{\prime \prime} \mathrm{E}$ and covers a total brackish water area of 4070.5 square meters. There is a flow 
station (sub-station where neighboring oil wells are pumped into a tank and re-routed into the main pipeline) at Krakrama with two horizontal flare stacks though not operational at the time of study (Figure 1).

\section{Materials and Methods}

The sampling was performed with a well calibrated equipment [MultiRAE PLUS (PGM-50)] and a programmable Multi Gas monitor with an electrochemical sensor. The parameters assessed were particulate matter of 1, 2.5, 7, 10 micron sizes $\left(\mathrm{PM}_{1-10}\right)$ and Total suspended particulate (TSP). These were monitored 1.5 meters above ground level for five months in 2012.

\section{Results and Discussions}

\section{$\mathbf{P M}_{10}$}

The $\mathrm{PM}_{10}$ results at Cawthorne Channels ranged from 313.6 upwind to $367.5 \mu \mathrm{g} / \mathrm{m}^{3}$ downwind with a mean of $340.55 \pm 38.11 \mu \mathrm{g} / \mathrm{m}^{3}$ in January, dry season. The wet season data ranged from $10.3-160.0 \mu \mathrm{g} / \mathrm{m}^{3}$, with a mean of $91.23 \pm 77.3 \mu \mathrm{g} / \mathrm{m}^{3}$ upwind and $10.5-180.2 \mu \mathrm{g} / \mathrm{m}^{3}$, with a mean of $101.43 \pm 85.4 \mu \mathrm{g} / \mathrm{m}^{3}$ downwind. The result showed strong seasonal variations with very high concentration in January $\left(313.6 \mu \mathrm{g} / \mathrm{m}^{3}\right)$ at upwind and 367.5 $\mu \mathrm{g} / \mathrm{m}^{3}$ downwind (Figure 2). The wet season data constituted the lowest data, especially in the month of September when the lowest value of $10.3 \mu \mathrm{g} / \mathrm{m}^{3}$ was obtained. In contrast, the highest PM 10 value was obtained in the month of January (Figure 2).

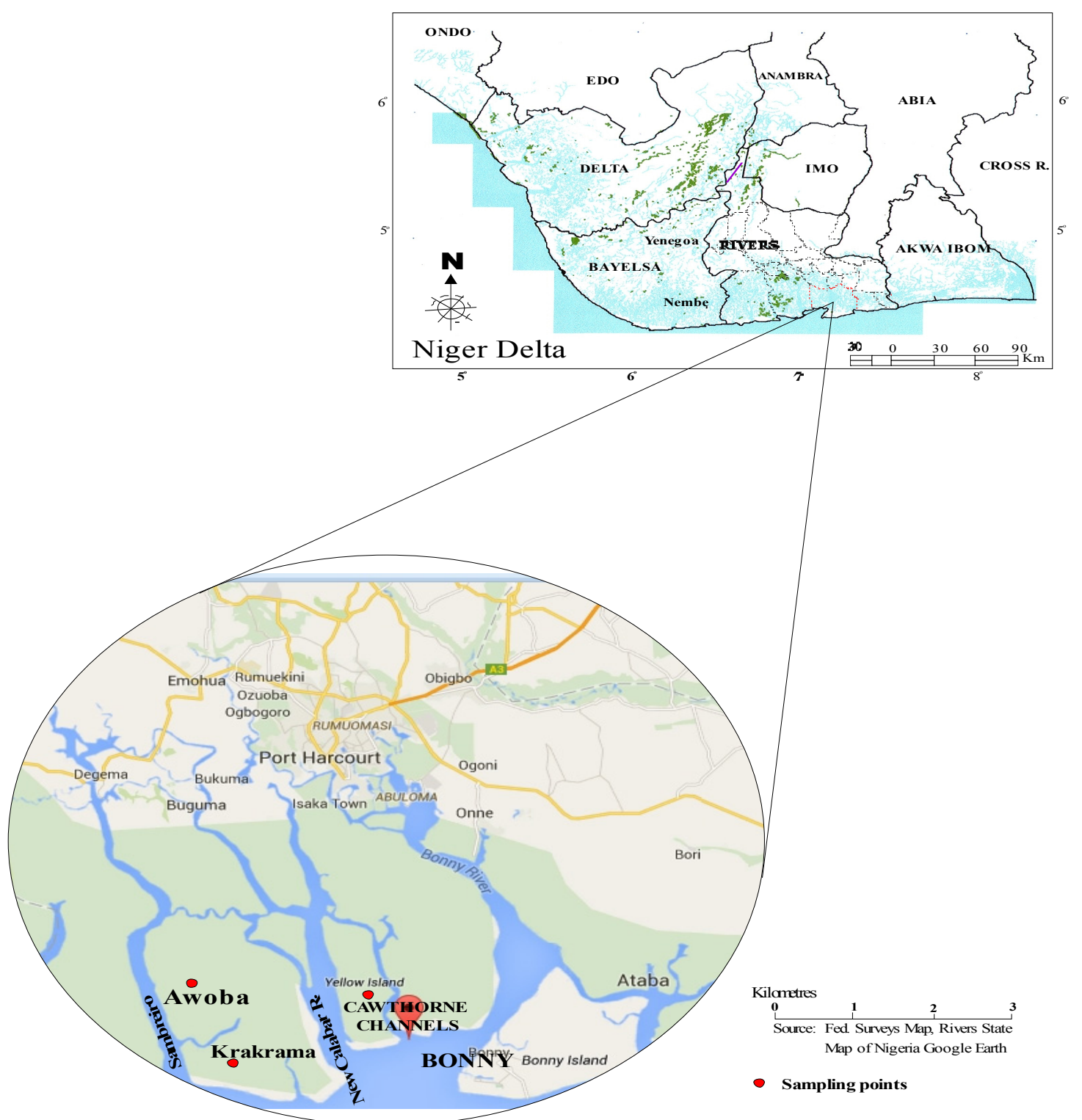

Figure 1. Map of Niger Delta (Nigeria) showing sampling stations 


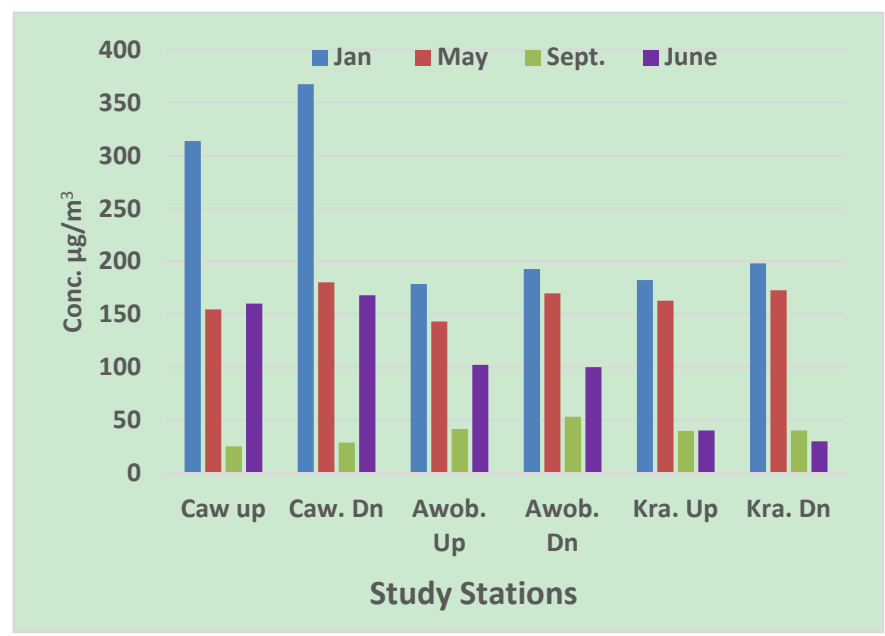

Figure 2. $\mathrm{PM}_{10}$ levels in wetlands air basin in Jan - June

Similarly, $\mathrm{PM}_{10}$ distribution from Awoba ranged from 178.5-192.8 $\mu \mathrm{g} / \mathrm{m}^{3}$ with a mean of $185.65 \pm 10.1 \mu \mathrm{g} / \mathrm{m}^{3}$ in January, dry season. The wet season distribution ranged from $16.9-143.2 \mu \mathrm{g} / \mathrm{m}^{3}$ with a mean of $82.05 \pm 53.7$ $\mu \mathrm{g} / \mathrm{m}^{3}$ upwind and $34.3-169.7 \mu \mathrm{g} / \mathrm{m}^{3}$ with a mean of $94.0 \pm 57.2 \mu \mathrm{g} / \mathrm{m}^{3}$ downwind. Similarly, PM 10 at Krakrama ranged from 182.4 to $198.1 \mu \mathrm{g} / \mathrm{m}^{3}$ with a mean of $190.25 \pm 11.10 \mu \mathrm{g} / \mathrm{m}^{3}$ in January, dry season. The wet season data ranged from 39.8 to $162.8 \mu \mathrm{g} / \mathrm{m}^{3}$ with a mean of $80.9 \pm 70.9 \mu \mathrm{g} / \mathrm{m}^{3}$ upwind, whereas it ranged from 30.0 to $172.6 \mu \mathrm{g} / \mathrm{m}^{3}$, with a mean of $80.9 \pm 79.6 \mu \mathrm{g} / \mathrm{m}^{3}$ downwind.

There was no statistical difference between data from upwind and downwind locations at Krakrama as $(\mathrm{p} \leq 1) .05$. Wet season values were generally lower than the dry data, with the lowest data being obtained from the month of September throughout all stations. Conversely, the dry season month, January had the highest data which exceeded international levels (Figure 2).

\section{$\mathbf{P M}_{7}$}

$\mathrm{PM}_{7}$ concentration at Cawthorne Channels, ranged from $266.7 \mu \mathrm{g} / \mathrm{m}^{3}$ at the upwind to $297.0 \mu \mathrm{g} / \mathrm{m}^{3}$ downwind, with a mean of $281.85 \pm 21.4 \mu \mathrm{g} / \mathrm{m}^{3}$ in January, being dry season (Figure 3). Similarly, the wet season data ranged from $9.4 \mu \mathrm{g} / \mathrm{m}^{3}$ to $112.7 \mu \mathrm{g} / \mathrm{m}^{3}$, with a mean of $61.05 \pm 73.04 \mu \mathrm{g} / \mathrm{m}^{3}$ upwind; whereas, at downwind, PM 7 ranged from 9.3 to $115.0 \mu \mathrm{g} / \mathrm{m}^{3}$, with a mean of $62.15 \mu \mathrm{g} / \mathrm{m}^{3}$. $\mathrm{PM}_{7}$, like others, displayed high seasonality but there was no significant difference between upwind and downwind. Similarly, in January being dry season, PM 7 at Awoba ranged from 110.0 at upwind to $165.0 \mu \mathrm{g} / \mathrm{m}^{3}$ downwind, with a mean of $137.5 \pm 38.9 \mu \mathrm{g} / \mathrm{m}^{3}$. In the wet season, PM 7 ranged from 10.2-98.2 $\mu \mathrm{g} / \mathrm{m}^{3}$, with a mean of $54.2 \mu \mathrm{g} / \mathrm{m}^{3}$ upwind and $10.8-124.8 \mu \mathrm{g} / \mathrm{m}^{3}$, with a mean of $67.8 \mu \mathrm{g} / \mathrm{m}^{3}$ downwind. September was the month with the lowest value while January had the highest concentration.

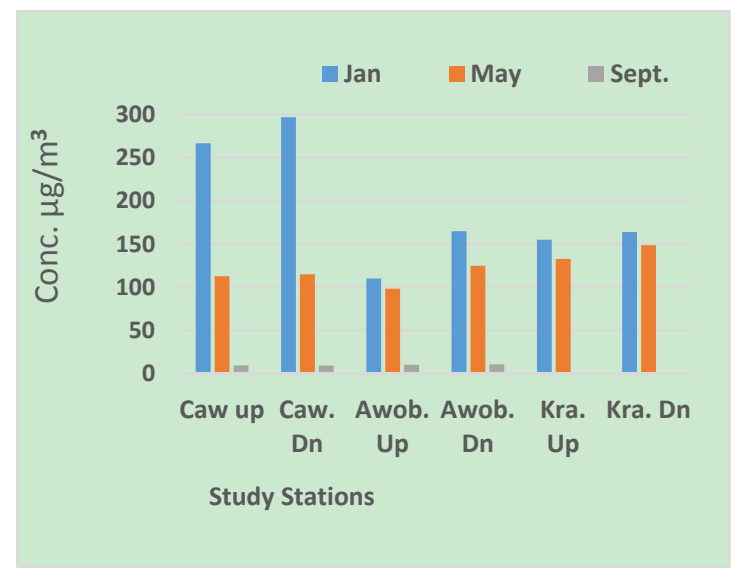

Figure 3. $\mathrm{PM}_{7}$ levels in wetlands air basin in Jan - June 
At Krakrama station, PM 7 ranged from $155.0-164.0 \mu \mathrm{g} / \mathrm{m}^{3}$ with a mean of $159.5 \pm 6.4 \mu \mathrm{g} / \mathrm{m}^{3}$ in January; while in wet season, a range of $132.8-148.7 \mu \mathrm{g} / \mathrm{m}^{3}$ was observed, with a mean of $140.8 \pm 11.2 \mu \mathrm{g} / \mathrm{m}^{3}$ (Figure 3). At Krakrama, like other stations, the lowest data was recorded in September while the highest was observed in January.

$\mathbf{P M}_{2.5}$

$\mathrm{PM}_{2.5}$ concentrations in January at Cawthorne Channels ranged from $48.9 \mu \mathrm{g} / \mathrm{m}^{3}$ to $59.7 \mu \mathrm{g} / \mathrm{m}^{3}$ in the dry season, with a mean of $54.3 \pm 7.6 \mu \mathrm{g} / \mathrm{m}^{3}$ (Figure 4); while in the wet season, it ranged from 2.2 to $40.9 \mu \mathrm{g} / \mathrm{m}^{3}$, with a mean of $21.55 \pm 27.4 \mu \mathrm{g} / \mathrm{m}^{3}$ upwind and 2.2 to $46.3 \mu \mathrm{g} / \mathrm{m}^{3}$, with a mean of $24.25 \pm 31.2 \mu \mathrm{g} / \mathrm{m}^{3}$ downwind.

$\mathrm{PM}_{2.5}$ data from Awoba ranged from 41.1-43.2 $\mu \mathrm{g} / \mathrm{m}^{3}$ in January, dry season. In wet season, PM 2.5 ranged from 8.9-36.4 $\mu \mathrm{g} / \mathrm{m}^{3}$, with a mean of $22.7 \pm 19.5 \mu \mathrm{g} / \mathrm{m}^{3}$ upwind and 9.3 to $41.2 \mu \mathrm{g} / \mathrm{m}^{3}$, with a mean of $25.3 \pm 22.6 \mu \mathrm{g} / \mathrm{m}^{3}$ downwind. There was no statistical difference between the up and downwind locations at Awoba $(\mathrm{p}<1)_{0.05}$. The month with the lowest data was September while January had the highest data.

At Krakrama in January, $\mathrm{PM}_{2.5}$ concentrations ranged from $42.7-48.2 \mu \mathrm{g} / \mathrm{m}^{3}$ with a mean of $45.5 \pm 3.9 \mu \mathrm{g} / \mathrm{m}^{3}$. In the wet season, PM 2.5 ranged from $32.5-40.6 \mu \mathrm{g} / \mathrm{m}^{3}$ (Figure 4).

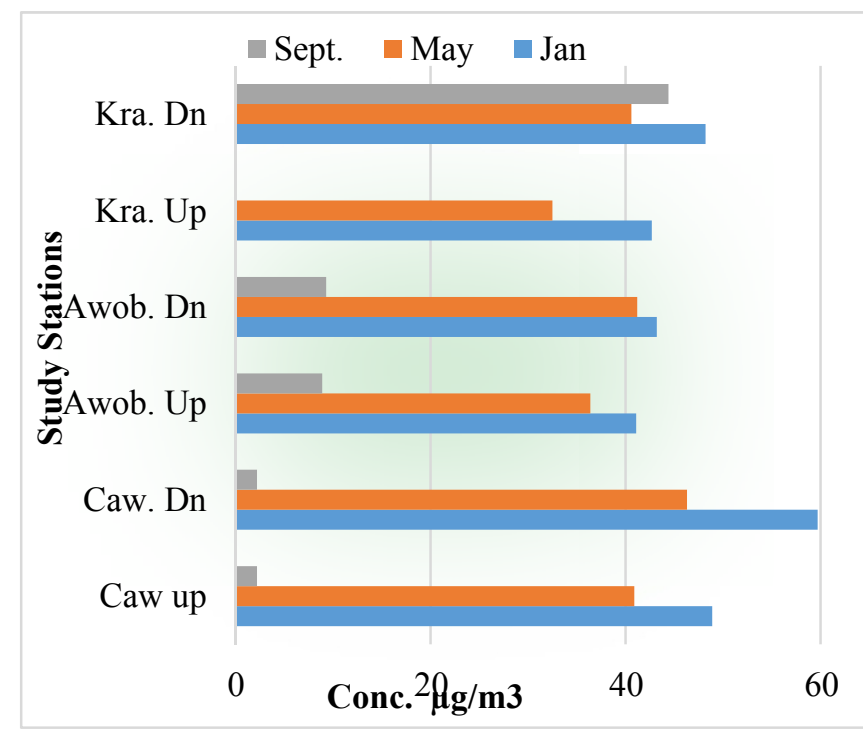

Figure 4. $\mathrm{PM}_{2.5}$ levels in wetlands air basin in Jan. - June

\section{$\mathbf{P M}_{1}$}

PM 1 concentrations at Cawthorne Channels ranged from 7.5 to $9.1 \mu \mathrm{g} / \mathrm{m}^{3}$ in January, with a mean of $8.3 \pm 1.1$ $\mu \mathrm{g} / \mathrm{m}^{3}$; while in wet season, PM 1 ranged from $0.5-6.3 \mu \mathrm{g} / \mathrm{m}^{3}$ with a mean of $2.9 \pm 3.4 \mu \mathrm{g} / \mathrm{m}^{3}$ (Figure 5). Data from Awoba ranged from 6.1-6.9 $\mu \mathrm{g} / \mathrm{m}^{3}$ in January, with a mean of $6.5 \pm 0.6 \mu \mathrm{g} / \mathrm{m}^{3}$; while the wet season PM 1 ranged from $1.4-6.8 \mu \mathrm{g} / \mathrm{m}^{3}$, with a mean of $3.85 \pm 2.6 \mu \mathrm{g} / \mathrm{m}^{3}$ (Figure 5 ).

At Krakrama, PM 1 ranged from 7.1-8.5 $\mu \mathrm{g} / \mathrm{m}^{3}$ in January, with a mean of 7.8 \pm 1.0 . In wet season, PM 1 ranged from 5.6-7.2 $\mu \mathrm{g} / \mathrm{m}^{3}$, with a mean of $6.4 \pm 1.1 \mu \mathrm{g} / \mathrm{m}^{3}$. 


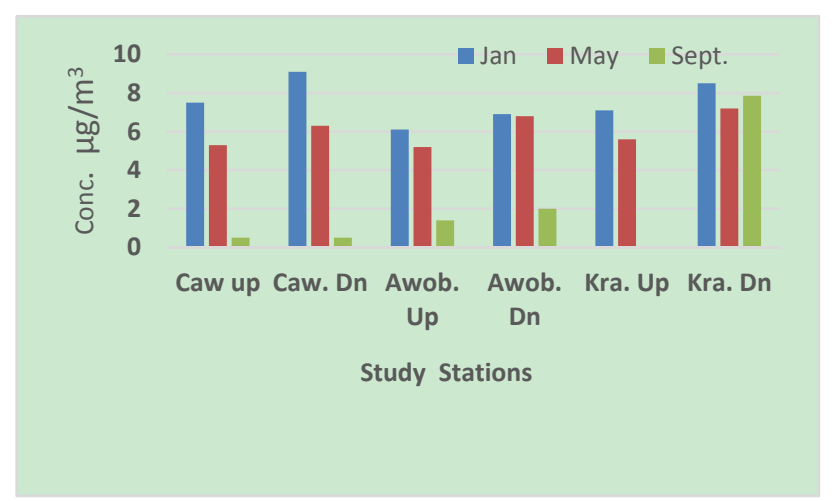

Figure 5. $\mathrm{PM}_{1}$ levels in wetlands air basin in Jan. - Sept

\section{TSP}

Total suspended particulate concentrations at Cawthorne Channels ranged from 346.1 to $401.7 \mu \mathrm{g} / \mathrm{m}^{3}$ in January, with a mean of $373.9 \pm 39.3 \mu \mathrm{g} / \mathrm{m}^{3}$ (Figure 6). Similarly, the wet season data ranged from $10.4 \mu \mathrm{g} / \mathrm{m}^{3}$ upwind to $215.2 \mu \mathrm{g} / \mathrm{m}^{3}$, with a mean of $112.6 \mu \mathrm{g} / \mathrm{m}^{3}$. January was the month with highest data while September was the month with lowest data. TSP data from Awoba ranged from 198-200.0 $\mu \mathrm{g} / \mathrm{m}^{3}$, with a mean of $199 \pm 1.3 \mu \mathrm{g} / \mathrm{m}^{3}$ in January. Conversely, the wet season data ranged from $34.8-193.4 \mu \mathrm{g} / \mathrm{m}^{3}$ with a mean of $114.3 \pm 83.0 \mu \mathrm{g} / \mathrm{m}^{3}$. Like other stations, September had the lowest value while January had the highest data.

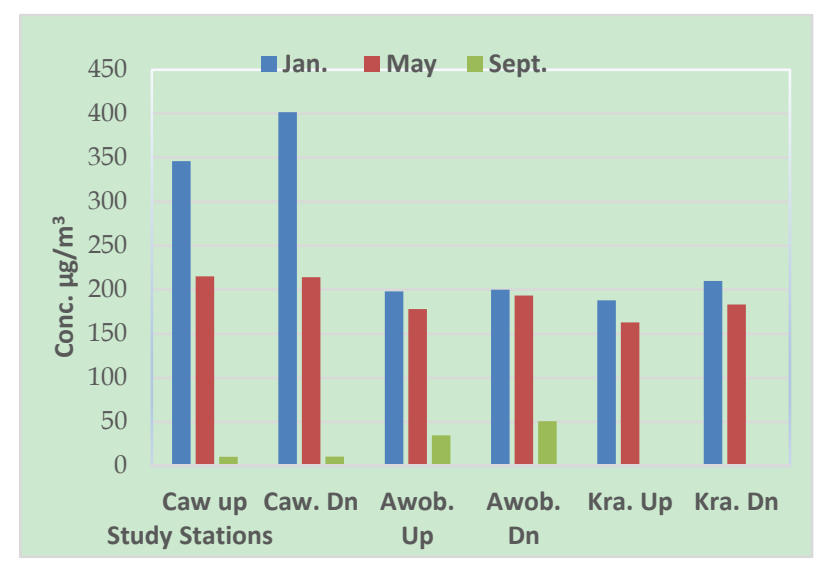

Figure 6. TSP levels at wetland air basin in Jan. and Sept

At Krakrama, TSP ranged from $188.0-210.0 \mu \mathrm{g} / \mathrm{m}^{3}$ in January, with a mean of $199.7 \pm 15.6 \mu \mathrm{g} / \mathrm{m}^{3}$. In wet season, TSP ranged from $162.9-183.4 \mu \mathrm{g} / \mathrm{m}^{3}$, with a mean of $173.2 \pm 14.5 \mu \mathrm{g} / \mathrm{m}^{3}$. Of all stations studied,

Cawthorne Channels had the highest data in all fractions followed by krakrama (Figures 2-6).

\section{Discussion}

The observed PM 10 concentrations were higher than International allowable limit of $150.0 \mu \mathrm{g} / \mathrm{m}^{3}$ (WHO, 2005) in the dry season. This may be attributed to the hamattan season, which is dust laden and also gas flaring operations. Gas flaring involves the combustion of natural gas in a controlled manner. This combustion process produces particulate matter of various fractions in addition to some gases.

Low values in wet season months (May, June and September) are due to the scavenging mechanism of precipitation (USEPA, 1990). USEPA reports that rainfall washes particulate away from the atmosphere thereby leading to particulate reduction. Among all the meteorological parameters, precipitation has been shown to have the greatest influence on particulate air quality. Rainfall has the effect of reducing re-entrainment of particle and washing them out of the air (USEPA, 1990). However, variations in downwind and upwind were not remarkable.

\section{PM 7}

Levels of $\mathrm{PM}_{7}$ above $150.0 \mu \mathrm{g} / \mathrm{m}^{3}$ occurred at all stations. The reasons for these increases may be due to the gas 
flaring emissions and hamattan effect. Low results obtained in wet season months (May and September) are attributed to precipitation effects. International allowable limits were exceeded at all sites except one, Awoba.

\section{$\mathbf{P M}_{2.5}$ and $\mathbf{P M}_{1}$}

$\mathrm{PM}_{2.5}$ and $\mathrm{PM}_{1}$ had values that were lower than the international allowable limit of $65.0 \mu \mathrm{g} / \mathrm{m}^{3}$ (WHO, 2005). The result also showed that much of the particulate in the air was in the coarse fraction of particle size of 10 microns $\left(\mathrm{PM}_{10}\right)$ and 7 microns $\left(\mathrm{PM}_{7}\right)$. Of all the size fractions studied, allowable International Standard according to USEPA (1990), was exceeded in $\mathrm{PM}_{10}$ and $\mathrm{PM}_{7} . \mathrm{PM}_{2.5}$ had values that were generally below 60.0 $\mu \mathrm{g} / \mathrm{m}^{3}$ while $\mathrm{PM}_{1}$ had values below $10.0 \mu \mathrm{g} / \mathrm{m}^{3}$ (Figures. $4 \& 5$ ). These are the fine fractions that can be inhaled into the alveoli and bronchioles of the lungs.

\section{TSP}

Total Suspended Particulate Matter (SPM) for Krakrama and Awoba were within the same range (188.0 - 210.0 $\mu \mathrm{g} / \mathrm{m}^{3}$ ) and much below the Nigerian National Standard of $250.0 \mu \mathrm{g} / \mathrm{m}^{3}$ (Figure 6). The ambient Total Suspended Particulate Matter (TSP) reaching $401.7 \mu \mathrm{g} / \mathrm{m}^{3}$ and observed in January, shows impact of hammattan season.

Of all the size fractions studied, the allowable International Standard according to USEPA (1990), was exceeded in $\mathrm{PM}_{10}$ and $\mathrm{PM}_{7} . \mathrm{PM}_{2.5}$ had values that were generally below $60 \mu \mathrm{g} / \mathrm{m}^{3}$ while $\mathrm{PM}_{1}$ had values below $10.0 \mu \mathrm{g} / \mathrm{m}^{3}$. As would be expected, there was a gradual decrease in particulate concentrations of lower sizes in this order: $\mathrm{PM}_{10}>\mathrm{PM}_{7}>\mathrm{PM}_{2.5}>\mathrm{PM}_{1}$. Particulate sizes and very low wet season (September) data were common at all air basins and size fractions.

\section{Acknowledgement}

We like to thank Daewoo Nigeria Limited for the provision of logistics to the site for sample collection during the period of the study. Our thanks also goes to the field men who helped to execute the job successfully.

\section{References}

Abbey, D. E., Hwang, B. L., Burchette, R. J., Vancuren, T., \& Milss, P. K. (1995). Estimated Long-Term Ambient Concentrations of PM10 and Development of Respiratory Symptoms in Nonsmoking Population. Arch Environ Health, 50(2), 139-151. http://dx.doi.org/10.1080/00039896.1995.9940891

Atkinson, R., Bremner, S., Anderson, H., Strachan, D., \& Bland, J. M. (1999). Short- term Association between Emergency Hospital Admissions for Respiratory and Cardiovascular Disease and Outdoor Air Pollution in London. Arch Environ health, 54(6), 399-411. http://dx.doi.org/10.1080/00039899909603371

Burnett, R., Cakmak, S., Brook, J., \& Krewaki, D. (1997). The Role of Particulate Size and Chemistry in the Association between Summertime Ambient Air Pollution and Hospital for Cardiorespiratory Diseases. Environ Health Perspec, 105(6), 614-620. http://dx.doi.org/10.1289/ehp.97105614

Estokova, A., \& Stevulova, N. (2012). Investigation of Suspended and Settled Particulate Matter in Indoor Air. Atmospheric Aerosols - Regional Characteristics - Chemistry and Physics. p480. http://dx.doi.org/10.5772/46130

Greenfacts Organization. (n. d.). Particulate matter. Retrieved January 26, 2015, from Https://www.greenfacts.org/Glosary/pqrs/Particulatematter.htm

Gwinn, M. R., \& Vallyathan, V. (2006). Environ. Health Perspec., 14,1818.

Heal, M. R., Hibbs, L. R., Agius, R. M., \& Beverland, I. J. (2005). Atmos. Environ., 39, 1417. http://dx.doi.org/10.1016/j.atmosenv.2004.11.026

Hinds, W. C. (1999). Aerosol technology: Properties, Behavior and Measurement of Airborne Particles. New York: Wiley. 483 p.

Joksić, J., Jovašević-Stojanović, M., Alena Bartonova, A., Radenković, M., Yttri, K.-E., Matić-Besarabić, S., \& Ignjatović, L. (2009). Physical and chemical characterization of the particulate matter suspended in aerosols from the urban area of Belgrade. J. Serb. Chem. Soc., 74(11), 1319-1333. http://dx.doi.org/10.2298/JSC0911319J

Kaonga, N., \& Kgabi, A. (2009). Atmospheric Particulate Matter in the Marikana Mining Area of Rustenburg, South Africa. European Journal of Scientific Research, 34(2), 271-279.

Morawska, L., \& Salthammer, T. (2003). Indoor Environment: Airborne Particles and Settled Dust. Weinheim: Wiley-VCH. 450 p. http://dx.doi.org/10.1002/9783527610013

Pope, C. A., \& Burnett, R. T. (2002). Lung Cancer, Cardiopulmonary Mortality, and Long-term Exposure to Fine 
Particulate Air Pollution. Journal of the American Medical Association, 287, 1132-1141. http://dx.doi.org/10.1001/jama.287.9.1132

Pope, C. A., Bates, D., \& Raizenne, M. (1995). Health Effects of Particulate Air Pollution: Time for Reassessment? Environ Health Perspec, 103, 472-480. http://dx.doi.org/10.1289/ehp.95103472

Reiss, R., Anderson, E. L., Cross, E. C., Hidy, G., Hoel, D., McClellan, R., \& Moolgavkar, S. (2007). Inhal. Toxicol., 19, 419. http://dx.doi.org/10.1080/08958370601174941

Schwartz, J. (1993a). Particulate Air Pollution and Hospital Emergency Room Visits for Asthma in Seattle. Am Rev Respir Dis., 147, 826-831. http://dx.doi.org/10.1164/ajrccm/147.4.826

Schwartz, J. (1993b). Air Pollution and Hospital Admissions for Elderly in Birmingham, Alabama. Am $J$ Epidemiol, 139(6), 589-598.

Seinfeld, J. H., \& Pandis, S. N. (2006). Atmospheric Chemistry and Physics; From Air Pollution to Climate Change. John Wiley and Sons, Inc.

USEPA. (1990). National Air Quality and Emissions Trends Report, 1998. Technical Support Division, US Environmental Protection Agency, Office of Air and Radiation, Office of Air Quality Planning and Standards Research Triangle Park, N. Carolina 2711, EPA-450/4-90-011.

USEPA. (2012). United States Environmental Protection Agency Glossary of Climate Change Terms. Particulate Matter.

\section{Copyrights}

Copyright for this article is retained by the author(s), with first publication rights granted to the journal.

This is an open-access article distributed under the terms and conditions of the Creative Commons Attribution license (http://creativecommons.org/licenses/by/3.0/). 